\title{
Dos muros às \\ frestas: a \\ irmandade Nossa \\ Senhora da \\ Lampadosa como \\ espaço étnico- \\ cultural
}

\section{Layla Silva Ferreira*}

DOI: 10.11606/issn.2318-8855.v10i1p360-382

Resumo: Este artigo tem como objetivo refletir sobre a Irmandade Nossa Senhora da Lampadosa, localizada no centro do Rio de Janeiro, por meio das suas festas. Como objeto, será analisada a Coroação de Reis da nação Cabundá, realizada em outubro de 1811. Nesse sentido, é possível que se desenvolva um estudo étnico-cultural, pensando nas nações dos escravizados que compunham a Irmandade e suas sociabilidades. Ou seja, a construção de suas identidades por meio da cultura da Coroação de Reis. Assim, o âmbito cultural e da sociabilidade étnica são os centros desta análise, preocupada com a formação de identidades.

Palavras-chaves: Coroação de Reis Negros; Cultura; Etnia; Irmandade Negra.

Abstract: This article aims to reflect upon the Brotherhood of Nossa Senhora da Lampadosa, placed in downtown Rio de Janeiro, through its celebrations. As an object, the Coronation of Kings of the Cabundá nation, realized in October 1811, will be analyzed. In this regard, it is possible to develop an ethnic-cultural study, thinking of the nations of the enslaved people that were part of the Brotherhood and its sociability. In other words, the construction of their identities through the culture of the Coronation of Kings. Thus, the cultural scope and ethnic sociability are the centers of this analysis, concerned with the formation of identities.

Palavras-chaves: Coroação de Reis Negros; Cultura; Etnia; Irmandade Negra.

* Graduanda em História na Universidade Federal do Rio de Janeiro. Foi bolsista PIBIC/UFR entre ago/2018-set/2020 orientada pelo Prof. Dr. Flávio dos Santos Gomes. Agradeço ao mesmo por todas as orientações prestadas e ao Programa Institucional de Bolsas da UFRJ pelo amparo, tornando viável os resultados que serão apresentados neste artigo. 


\section{artigos}

\section{Dos muros às frestas}

\section{Introdução}

O artigo que aqui será apresentado em toda sua extensão encontra-se sob a égide da História Cultural ${ }^{1}$ e foi desenvolvido após uma série de leituras historiográficas sobre o Brasil Escravista. Dessa maneira, buscou-se identificar diversas formas de manifestações culturais, construção de comunidades e organizações de protestos, sendo as Irmandades Negras uma das principais organizações que se fundamentavam em torno destas três premissas. ${ }^{2}$

Assim, foi necessário trazer à tona a discussão sobre a questão étnica pautada nas chamadas "identidades contrastivas", ou seja, que se definem em contraposição a outras previamente estabelecidas ${ }^{3}$ e que explicam a problemática de "reorganização", de surgimento de "novas devoções e novos rearranjos entre os grupos" (SOARES, 1998, p.138). Outrossim, a fim de pensar sobre a questão étnica de forma não-ampla, tornou-se válido observar a discussão proposta pela historiadora Mariza Soares, a qual realiza em sua obra uma grande crítica em relação à ideia de nação como mecanismo de identificação e organização dos africanos nas Américas, preferindo atentarse às fronteiras entre os grupos étnicos por meio da formação de arranjos mais inclusivos, os quais chamará de "grupos de procedência"4 - sistemas sociais abrangentes -,

\footnotetext{
1 "O conceito de cultura aqui adotado distancia-se da ideia de busca de traços originais de características puras e uma quase inata atitude auto regeneradora, resistente à mudança". SOARES, Mariza de Carvalho. Mina, Angola e Guiné: nomes d'África no Rio de Janeiro setecentista. Tempo, Vol. 3 $n^{\circ} 6,1998$.

2 Conforme destaca João José Reis, as Irmandades funcionavam como "meios de afirmação cultural. Todavia, com o passar do tempo, as irmandades serviram como "espaço de alianças inter-étnicas". REIS, João J. A morte é uma festa: ritos fúnebres e revolta popular no Brasil do século XIX. São Paulo. Companhia das Letras, 1991.

${ }^{3}$ Nesta argumentação, Mariza Soares faz referência à noção de identidade contrastiva proposta pelo antropólogo Roberto Cardoso de Oliveira. Identidade, etnia e estrutura social. São Paulo. Pioneira. 1976.

${ }^{4}$ Mariza de Carvalho Soares. Devotos da cor. Identidade étnica, religiosidade e escravidão no Rio de Janeiro, século XVIII. Rio de Janeiro: Civilização Brasileira. 2000. No trabalho em questão, a autora detalha a
} 


\section{artigos}

\section{Layla Silva Ferreira}

trazendo à tona o debate de solidariedade e sociabilidade entre estes. Dessa maneira, ao pensar de forma figurativa, a construção de identidades étnicas formou os "muros" da Irmandade Nossa Senhora da Lampadosa, localizada na área central do Rio de Janeiro.

Logo, tornou-se notória a necessidade da discussão sobre a Irmandade Negra em questão, a fim de mapear seus personagens, origens étnicas e formas culturais a partir dos vestígios deixados sobre as festas da Irmandade ${ }^{5}$, tendo como principais fontes documentais aquelas relacionadas às festividades de coroações de Reis e Rainhas da associação. Assim, busca-se localizar determinados grupos africanos ${ }^{6} \operatorname{com}$ objetivo de examinar aspectos simbólicos e representativos da Irmandade entre os arranjos coletivos negros, associativismos e suas práticas políticas e culturais cotidianas no contexto do Brasil Escravista.

A partir disso, coube observar outras características das Irmandades Negras, atentando-me às "frestas"7 dos diversos documentos que foram analisados ao longo

inspiração nos trabalhos do antropólogo Fredrik Barth. Atrela, ademais, ao conteúdo trazido pelo historiador Paul Lovejoy que alerta para o fato de que, como resultado da migração forçada da escravidão, as identificações étnicas podem se tornar mais inclusivas.

${ }^{5}$ A fim de esmiuçar e ilustrar o cruzo entre etnia e cultura, cabe recorrer à uma extensa passagem de Mariza Soares. Para a historiadora, "o conceito de identidade étnica busca suporte no próprio conceito de cultura. Do mesmo modo que cultura é definida por "formas culturais", também a identidade étnica é um conceito no qual está pressuposto um processo marcado por sucessivas apropriações. Tanto a cultura quanto a identidade étnica de um grupo estão em estreita ligação com as condições de vida da sociedade a na qual estão inseridos". SOARES, Mariza de Carvalho. Mina, Angola e Guiné: nomes d'África no Rio de Janeiro setecentista. Tempo, Vol. $3 n^{\circ} 6,1998$

${ }^{6}$ Sob a égide teórica de Natalie Davis, onde destaca a possibilidade de analisar eventos festivos para entender, por um lado, como eles podem "perpetuar certos valores da comunidade". Logo, as festas aparecem como meio de analisar uma "comunidade". DAVIS, N.Z. 1990. Culturas do povo: Sociedade e cultura no início da França Moderna. Rio de Janeiro, Paz e terra.

7 O conceito de "fresta" foi desenvolvido pela historiadora Maria Clementina Pereira da Cunha. Utilizo, dando os devidos créditos, com a mesma intenção da autora em questão: pensar as festas como frestas de uma sociedade. Ver em: CUNHA, Maria Clementina Pereira. Carnavais e outras $f(r)$ estas: ensaios da história social da cultura. Editora UNICAMP, 2001. 
da pesquisa. Através da observação da privilegiada documentação elaborada pelos confrades da Irmandade, como os estatutos ou compromissos, e os seus requerimentos e petições, nos quais solicitavam auxílios para festejos, por exemplo, pretende-se empregar como método o cruzamento de fontes de diferentes naturezas. ${ }^{8}$

\section{Formação de identidades: os "muros" da Irmandade Nossa Senhora da Lampadosa}

Nos últimos cinquenta anos, após uma virada teórica no campo do estudo das sociedades escravistas, a historiografia brasileira se preocupou, de forma mais ativa, com temas como identidades e cultura dos africanos e seus descendentes. ${ }^{9}$ No Brasil, diversos pesquisadores têm-se inclinado a pensar as mais variadas possibilidades metodológicas a fim de entender as formações das identidades e os sistemas de identificação dos escravizados. ${ }^{10}$ Ao pensar nas origens destes africanos, o estudo mais abrangente sobre o tema é o principal trabalho da historiadora norte-americana Mary

\footnotetext{
8 A pesquisa aqui apresentada recorre ao método de cruzamento de fontes eclesiásticas e nãoeclesiásticas, ou seja, de diferentes "origens". Ao pensar no método de cruzamento de fontes, recorro a Carlo Ginzburg, que apresentou tal metodologia em um dos seus maiores feitos. Ver em GINZBURG, Carlo. O queijo e os vermes: o cotidiano e as ideias de um moleiro perseguido pela Inquisição. São Paulo, Companhia das Letras, 2017

${ }^{9}$ A História da Escravidão no Brasil e nas Américas, entrou numa grande revisão ao longo da década de 1970. Dessa forma, os historiadores voltaram-se para a análise da vida escrava a partir da ótica da organização do trabalho e das transformações das relações sociais ao longo do tempo, em busca do estudo da autonomia escrava. Em meados da década de 70, Sidney Mintz e Richard Price, por exemplo, defendiam que o impacto do tráfico atlântico havia sido capaz de destruir identidades preexistentes, enfatizando a importância de uma nova cultura afro-americana MACHADO, Maria Helena. Em torno da autonomia escrava: uma nova direção para a história social da escravidão. Revista Brasileira de História, São Paulo, vol. 8, n. 16, 143-160, 1998; Sidney W. Mintz \& Richard Price - The birth of African-American Culture. Boston, Beacon Press,1992. DEMÉTRIO, Denise Vieira. Famílias escravas no Recôncavo da Guanabara: séculos XVII e XVIII. Niterói. Dissertação (Mestrado) - Instituto de Ciências Humanas e Filosofia, Universidade Federal Fluminense, Niterói. 2008.

10 Ver em: REIS, João José. Identidade e diversidade étnica nas irmandades negras no tempo da escravidão. Tempo, Rio de Janeiro, v.2, n.3, p.7-33. 1997; SLENES, Robert. Malungu Ngoma vem! A África coberta e descoberta do [no] Brasil. Revista USP, n.12, dez.-fev, p.48-67. 1991-1992. Dentre outros.
} 


\section{artigos}

Layla Silva Ferreira

C. Karasch, que, ao utilizar diferentes tipos de fontes, consegue mapear diversas áreas de concentração africana de escravizados, e, mais do que isso, contribui para a "identificação das origens africanas de muitos tipos de cultura material e de rituais religiosos" (KARASCH, 2000. p. 33).

Durante a primeira metade do século XIX, a escravidão no Rio de Janeiro viveu o maior impacto do tráfico atlântico. Nenhuma outra cidade nas Américas se aproximou do quantitativo da população escrava do Rio durante o período. A partir dos cálculos de Karasch, o período em questão contou com a maior quantidade de escravizados no Rio de Janeiro. No que diz respeito ao desembarque, segundo a historiadora, o número chegou a ultrapassar 600 mil. Sobre a temática abordada, diversas revisões foram realizadas atentando-se para o volume do tráfico nas diferentes regiões das Américas. ${ }^{11}$

Para além disso, o início do século XIX também teve como marco a chegada da corte portuguesa, que causou impacto na escravidão africana ao atrair a mão de obra escrava para a Corte do Império, o que aumentou a demanda por escravizados e impulsionou o tráfico, dobrando a média de importação. Outrossim, em consequência, "a data marcou também o começo do significativo tráfico atlântico para o Rio de Janeiro, que trouxe tantos negros do Centro-Oeste Africano para a cidade". (KARASCH, 2000, p.29). De acordo com a pesquisa de Karasch, os africanos centrais - divididos entre Congo norte, sul e norte da Angola - representavam 79,7\%, já africanos orientais, 17,9\%. A pesquisadora ainda analisou 37 nomes como de "origem desconhecida" (KARASCH, 2000, p. 35 apud. GOMES, 2012, p. 94).

11 Estudos de quantificação foram revisitados por Florentino (1995) a partir de registos de desembarques de navios negreiros no Rio de Janeiro. 


\section{artigos}

Dos muros às frestas

Assim, segundo a análise do historiador Flávio Gomes, o aumento do número de africanos ocidentais “sugere pensar que, para além daqueles entrados no Rio via comércio da Bahia, navios vindos da Costa da Mina - com escala ou não em Salvador -, outros tinham por destino final o Rio de Janeiro e o seu consequente comércio" (GOMES, 2012, p.95). Ou seja, mesmo após a proibição do tráfico na costa ocidental, em 1815, africanos ocidentais continuaram a chegar à Corte Imperial. ${ }^{12}$ Ao pensar na procedência desses escravizados ${ }^{13}$, é válido atentar-se à ótica de que os africanos se inventaram em termos de "nações" a partir de diversos arranjos (família, Irmandades Religiosas etc.), se articulando num cenário riquíssimo para análise, descobrindo “novas identidades sociais além dessas locais, e já múltiplas, que se formaram ao longo de seu caminho de sofrimento em direção à costa" (MILLER, 2008, p.53 apud. GOMES, 2012, p.103). Dessa maneira, as identidades eram remarcadas em termos étnicosociais, logo, os escravizados não tinham uma única identidade, mas várias ${ }^{14}$. Outrossim, Flávio Gomes salienta, que, ao pensar a demografia atlântica dos africanos, é

\footnotetext{
12 Manolo Florentino desvenda os mecanismos do tráfico atlântico com destino ao Rio de Janeiro em: FLORENTINO, Manolo Garcia. Em costas negras: uma história do tráfico atlântico de escravos entre a África e o Rio de Janeiro (séculos XVIII e XIX). Rio de Janeiro: Arquivo Nacional. 1995.

${ }^{13}$ Mariza Soares chama atenção para a noção de "grupo de procedência", se aproximando do que o antropólogo Frederik Barth chamou de "grupo étnico", preocupado com as questões organizacionais. Segundo o antropólogo, "não há uma simples relação biunívoca entre grupos étnicos e semelhanças ou diferenças culturais, já que cada grupo seleciona componentes da cultura que considera mais significativos". Assim, é nessa ótica que a historiadora chama atenção para a possibilidade dos tais grupos de procedência, em condições diversas, se organizarem de formas diferentes. Ver em: Mariza de Carvalho Soares. Devotos da cor. Identidade étnica, religiosidade e escravidão no Rio de Janeiro, século XVIII. Rio de Janeiro: Civilização Brasileira. 2000.

${ }^{14}$ A fim de esmiuçar o assunto da construção de identidades, ver: FARIAS, Juliana Barreto; GOMES, Flávio dos Santos; SOARES, Carlos Eugênio Líbano. No labirinto das nações: africanos e identidade no Rio de Janeiro, século XIX. Rio de Janeiro: Arquivo Nacional. 2005.
} 
Layla Silva Ferreira

possível notar diferentes combinações de nomenclaturas e termos que podiam aparecer ou desaparecer dependendo do período e das fontes consultadas. ${ }^{15}$

Dessa forma, coube aos historiadores, preocupados com as relações sociais e culturais dos escravizados, descortinar as névoas das fontes documentais. Mariza Soares, em sua tese de doutorado, demonstrou que a organização dos africanos pôde resultar de rearranjos étnicos estabelecidos no próprio cativeiro. Assim, a autora percebe que, conforme previamente mencionado, a maioria dos escritos estava baseado em categorias abrangentes, com o uso dos termos como "nação angola", "escravos da Guiné" e "preto-mina"16. Entretanto, em todos estes casos, a terminologia trazia, implicitamente, uma grande variedade de grupos étnicos. ${ }^{17}$ Por conseguinte, a historiadora busca utilizar a lógica do antropólogo Frederik Barth que salienta que cada indivíduo se posiciona de diferentes modos de acordo com as redes que estabelecem e/ou são inseridos, logo, os escravizados não se viam como angolas ou minas, antes

\footnotetext{
${ }^{15}$ Em sua análise, Flávio dos Santos Gomes entende que as variações “poderiam ser motivadas pelas conexões das classificações utilizadas no tráfico com as montagens transétnicas das primeiras experiências na diáspora, no caso, o Rio de Janeiro. Em: GOMES, Flávio dos Santos. A demografia atlântica dos africanos no Rio de Janeiro, séculos XVII, XVIII e XIX: algumas configurações a partir dos registros eclesiásticos. História, Ciências, Saúde-Manguinhos, v. 19, p. 81-106, 2012.

${ }^{16}$ A historiadora Mariza Soares observa que, em fontes eclesiásticas, o termo "gentio da Guiné", aos poucos, é redistribuído em "nações", atendendo às novas exigências do tráfico atlântico. Ver em: Mariza de Carvalho Soares, Devotos da cor. Identidade étnica, religiosidade e escravidão no Rio de Janeiro, século XVIII. Rio de Janeiro, Civilização Brasileira, 2000; de mesma autoria: "Mina, Angola e Guiné, nomes d'África no Rio de Janeiro Setecentista". Revista Tempo, vol. 3 - n 6, dezembro de 1998; e "A nação que se tem e a terra de onde se vem". Estudos Afro-Asiáticos, ano 26, mai-ago 2004: 303-330.

17 Em instigante trabalho sobre etnias africanas nas Américas, a estadunidense Gwendolyn Midlo Hall enfatiza que "o sentido em que se emprega o termo "nação" na documentação produzida nas Américas é múltiplo. Há uma escassez de estudos históricos aprofundados e conhecimento sistematizado sobre as etnias africanas no Novo Mundo, lacuna essa igualmente verificada na África. É fácil confundir-se diante do número de designações que aparecem para se referir a uma variedade de populações ao longo de 400 anos de tráfico pelo Atlântico. Portanto, o significado das "nações" e a designação étnica variam no tempo e no espaço". Ver em: HALL, Gwendolyn Midlo. Cruzando o Atlântico: etnias africanas nas Américas. Topoi, Rio de Janeiro, v.6, n.10, p.29-70. 2005.
} 
de serem identificados desta forma ${ }^{18}$, entretanto, incorporaram tais identidades e operaram a partir delas. Ou seja, o que o pesquisador norueguês propõe é pensar que a lógica da temática da identidade ultrapassa as questões de identidades étnicas, abrindo, dessa forma, para a problemática das identidades sociais de modo geral. ${ }^{19}$

Assim, no início do século XIX, as fontes eclesiásticas chamavam atenção para grupos étnicos mais específicos, como por exemplo Benguela e Cabinda ${ }^{20}$, no que diz respeito aos africanos de origem Ocidental. De acordo com Karasch, era do CentroOeste africano - dividido em Congo Norte (Cabinda), Angola e Benguela -, que vinha a maioria dos africanos do Rio de Janeiro (KARASCH, 2000, p.50). Outrossim, ligados ao Congo Norte, estavam os denominados congos, uma das nações mais numerosas da cidade, segundo a historiadora norte-americana.

Todavia, identificá-los é uma árdua tarefa. Isso porque os denominados congos, no Rio de Janeiro, por vezes, eram bacongos do Norte da Angola e do Sul de Zaire (hoje, República Democrática do Congo), entretanto, muitos outros grupos étnicos também eram denominados congos devido ao costume do tráfico atlântico que entendia que qualquer escravizado exportado pelos mercados ligados à rede do rio Zaire era

\footnotetext{
18 Segundo a tese de doutorado de Regiane Augusto de Mattos, "a identificação dos diferentes grupos étnicos africanos esteve presente desde os primeiros contatos dos portugueses com a África, por volta do século XV configurando-se, logo depois, uma das estratégias para a organização do tráfico de escravos". Ver em: MATTOS, Regiane Augusto de. De cassange, mina, benguela a gentio da Guiné: grupos étnicos e formação de identidades africanas na cidade de São Paulo (1800-1850). 2009. Tese de Doutorado. Universidade de São Paulo.

${ }^{19}$ Antropólogo norueguês, Frederik Barth é um nome fundamental para o debate em torno ao conceito de etnicidade. Ver: Fredrik Barth. O Guru, o iniciador e outras variações antropológicas. Rio de Janeiro: Contracapa. 2000; F. Barth (editor), Ethnic groups and boundaries: the social organization of culture difference, University Fortlaget: George Allen/Unwin: Bergen: London, 1969, p. 9-38.

20 De acordo com o levantamento de Mary C. Karasch, o significado destes termos variava muito e seu uso, no tráfico africano, não era consistente com a verdadeira identidade étnica. Ver em: KARASCH, Mary. A vida dos escravos no Rio de Janeiro, 1808-1850. São Paulo: Companhia das Letras. 2000.
} 


\section{artigos}

\section{Layla Silva Ferreira}

um congo. Na cidade do Rio de Janeiro, os congos eram conhecidos como um povo extremamente orgulhoso de suas tradições, celebrando o antigo reino do Kongo em suas canções, honrando o Rei Baltazar como o rei congo, coroando seus próprios reis e rainhas, conforme será esmiuçado ao longo deste trabalho.

Dessa forma, durante a primeira metade do século XIX, a grande maioria dos escravizados importados para o Rio de Janeiro eram provenientes de sociedades falantes da língua bantu. ${ }^{21} \mathrm{O}$ historiador Robert Slenes chama atenção para uma característica muito comum em todas as sociedades bantu: a questão da estruturação em torno da família, sendo esta entendida como uma linhagem, ou seja, “um grupo de parentesco que traça sua origem a partir de ancestrais comuns" (SLENES, 1999, p.151).

Assim, conforme já demonstrado, estudos contemporâneos têm se inclinado a entender as formações (e as transformações) das identidades escravizadas, africanas, e, até mesmo crioulas, na experiência da escravidão, atentando aos contextos atlânticos e transatlânticos das reinterpretações e reinvenções culturais ${ }^{22}$, mostrando, dessa forma, que numa grande área da África Centro-Ocidental "a cultura é menos heterogênea e menos particularista do que realmente se supõe" (VANSINA, 1976, p.475 apud SLENES, 2011 p. 151). ${ }^{23}$ Logo, “estudos mais recentes, pautados pela História

\footnotetext{
${ }^{21}$ Robert Slenes propõe a ideia da formação de uma "proto-nação bantu". Sobre a abordagem, João José Reis classifica-a como "refinada", já que o autor em questão sugere tal formação a partir de "características linguísticas comuns a vários povos oriundos da região Centro-Sul da África", indo na contramão da terminologia "negros bantos", usada anteriormente por historiadores e antropólogos, que, segundo o historiador baiano "explica muito pouco". Ver comentário em: REIS, João José. Identidade e diversidade étnicas nas irmandades negras no tempo da escravidão. Tempo, v. 2, n. 3, p. 733, 1996; Sobre a "proto-nação bantu", ver Robert Slenes, "'Malungo ngoma vem!": África encoberta e descoberta no Brasil", Revista USP, 12 (1991-92), pp. 48-67.

22 Ver: MILLER, Joseph C. Restauração, reinvenção e recordação: recuperando identidades sob a escravização na África e face à escravidão no Brasil. Revista de História, n. 164, p. 17-64, 2011

${ }^{23}$ Ao lado de Willy de Craemer e Renée C. Fox, Jean Vansina assinalou os valores culturais ligados ao
} 


\section{artigos}

Dos muros às frestas

Etnográfica, têm demonstrado como as comunidades escravas nas Américas fundamentalmente forjaram uma interação e transformação cultural original e diversificada. Isto, mesmo num mundo de muitas opressões" (GOMES; SOARES, 2001, p.4).

Ademais, em vista disso, pode-se entender que os africanos trazidos ao Rio de Janeiro teriam lutado para reorganizar seus laços étnicos a partir da família-linhagem, encontrando e/ou forjando condições para manter grupos estáveis, formando famílias, sejam estas conjugais ou de grupos de parentescos, como as Irmandades Negras, entendendo uma "herança cultural", como sugere Sidney Mintiz e Richard Price, comuns nas sociedades da África Centro-Ocidental. Ou seja, havia pluralidade cultural. "A cultura, portanto, deve ser lida no contexto das experiências históricas de seus agentes" (GOMES; SOARES, 2001, p.5). É sob esse prisma que este trabalho discutirá as relações étnicas no interior da Irmandade Nossa Senhora da Lampadosa no Rio de Janeiro escravista, a fim de debater a Coroação de Reis Negros (1748-1811).

Por fim, conforme já discutido, as identidades dos escravizados foram reinterpretadas, tecendo afinidades étnicas e construindo novas identidades a partir da bagagem cultural comum. Estas (re)organizações étnico-sociais se baseavam em diversas disposições, como as famílias. Entretanto, com a diluição dos laços familiares devido ao tráfico atlântico e interprovincial, os escravizados buscavam a reconstrução de elos, sendo o principal arranjo, a ligação entre malungos (ou seja, companheiros da dura travessia atlântica). Tal dificuldade no que diz respeito à formação de famílias fez com que os escravizados redefinissem a semântica da palavra "parente", cunhan-

conceito de "ventura-desventura" (fortune-misfortune), auxiliando a pensar as proximidades e ideias de parentesco entre escravizados da África Central no Brasil. Ver em: DE CRAEMER, Willy; VANSINA, Jan; FOX, Renée C. Religious movements in Central Africa: a theoretical study. Comparative studies in society and history, v. 18, n. 4, p. 458-475, 1976. 


\section{artigos}

\section{Layla Silva Ferreira}

do o termo "parente de nação"24, a fim de forjar parentescos simbólicos, revelando o grande impacto do sistema escravista para sociedades com estruturas de parentescos complexas que tiveram de reformular as significações de família desmantelada pela escravidão e dificilmente reconstruída em diáspora (REIS, 1991, p.68).

Isto posto, percebe-se que a organização étnica que aqui será abordada perpassa relações provenientes de "reuniões de grupos oriundos da mesma etnia ou de regiões próximas, pertencentes a um mesmo complexo sócio cultural" (SOUZA, 2002, p.181). As Irmandades Negras podem ser entendidas como espaços que compunham um importante papel na criação de grupos coesos mesmo sendo, por vezes, compostos por lentos díspares no que diz respeito à cultura. Assim, as Irmandades foram associações fundamentais e assumiam tarefas que deveriam ser de alçada do poder público, servindo de ajuda mútua, e, para além disso, ao se caracterizarem pelas festas e procissões, uniam elementos sagrados e profanos, sendo também um lugar de expressão cultural e manutenção da herança ancestral"25, "combinando elementos culturais em contato, isto é, africanos e lusitanos, as acompanhavam se inseriam num quadro geral da colonização do Novo Mundo e da constituição de identidades próprias aos grupos formadores dessas sociedades" (SOUZA, 2002, p.182).

\section{Entre as frestas culturais: a Coroação de Reis Negros em 1811}

\footnotetext{
${ }^{24}$ Antônia Aparecida Quintão utiliza tal lógica de "parente de nação" para intitular seu principal trabalho, onde descreve os aspectos religiosos, estratégias de resistência e solidariedade na perspectiva da sociedade escravagista na qual estavam inseridas ao realizar um estudo sobre as Irmandades Negras do Rio de Janeiro e Pernambuco no século XVIII.

25 O historiador baiano João José Reis chama atenção para o caráter barroco da religiosidade que as Irmandades Religiosas assumiam, caracterizadas pela pompa das procissões e cultos aos santos. Ademais, o autor chama atenção o processo de afirmação culturais, construção de identidades e alteridades desenvolvidas a partir das Irmandades Negras, mesmo sendo vistas, pelos senhores, como um espaço de "domesticação do espírito africano". Ver em: REIS, João José. A morte é uma festa: ritos fúnebres e revolta popular no Brasil do século XIX. Companhia das Letras, 1991; do mesmo autor: Identidade e diversidade étnicas nas irmandades negras no tempo da escravidão. Tempo, v. 2, n. 3, p. 733, 1996.
} 


\section{artigos}

Dos muros às frestas

O Rio de Janeiro oitocentista, para os escravizados, era repleto de "muros", muito diferente dos relatos de viagens de estrangeiros sobre o "paraíso tropical" da Corte. Esses muros podiam ser imaginários, como as relações étnicas e hierarquias sociais, conforme detalhado acima, ou concretos, como a "casa-grande" e mansões, que protegiam, explicitamente, a elite privilegiada da cidade. Segundo Mary Karasch, "da perspectiva do senhor de escravos, o Rio era idealmente situado, pois estava protegido das tempestades do Atlântico por uma bacia plácida e de ataques marítimos ou terrestres por seu sistema de fortificações e montanhas protetoras" (KARASCH, 2000, p.100). Ao se tratar da organização citadina, os escravizados viviam distribuídos em oito freguesias, sendo Sacramento da Sé, São José, Candelária e Santa Rita as que concentravam a maior atividade escravista no século XIX. Todas as freguesias contavam com pelo menos uma pequena igreja construída ainda no período colonial. Dessa forma, as igrejas e santuários ocupavam boa parte da paisagem do Rio de Janeiro.

As igrejas em questão podiam ou não abrigar irmandades religiosas compostas por crioulos e/ou africanos, sendo as de exclusiva entrada de africanos organizadas através da separação por "nações". As irmandades compostas, em maioria, por escravizados e libertos podiam ter a característica de devoção a santos pretos, como São Elesbão, Santa Ifigênia e São Benedito. Sobre essa questão, Anderson José Machado Oliveira chama atenção para a importância desses santos para a construção não só das irmandades mas também de identidades ao causar uma identificação imediata, fazendo com que a religião europeia passasse por uma releitura a partir das concepções religiosas dos negros pertencentes a esses grupos (OLIVEIRA, 2008, p.33).

Em um de seus trabalhos, Antônia Aparecida Quintão denomina as irmandades negras como "outro espaço de luta e resistência", tratando-as como um valoroso 


\section{artigos}

Layla Silva Ferreira

meio de não-aceitação do processo de coisificação, próprio da sociedade escravista (QUINTÃO, 2002, p.16). Dessa forma, essas associações atingiram grande importância social para os escravizados no que diz respeito à construção de "família-linhagem", conforme visto acima, ou seja, "serviram de veículo de transmissão de diversas tradições africanas, que se conservaram pela frequência dos contatos, pela conservação da língua e outras razões semelhantes" (SCARANO, 1975, p.150 apud MATTOS, 2006, p.139).

Logo, os escravizados, por sua vez, podiam frequentar boa parte das igrejas. Todavia, aquelas chamadas popularmente de "igrejas dos escravos" tinham de ser construídas longe dos centros políticos e comerciais da cidade. Assim, as mais frequentadas pelos africanos pouco constam nos relatos dos viajantes estrangeiros, como por exemplo, a Igreja do Rosário e de São Benedito e a Igreja da Nossa Senhora da Lampadosa (objeto deste artigo) ${ }^{26}$, ambas localizadas próximo à atual Praça Tiradentes. Outras também eram conhecidas por agrupar escravizados, como a São Elesbão e Santa Ifigênia ${ }^{27}$ e São Domingos, que ficavam próximas ao Morro do Castelo. Por fim, outros espaços também tinham caráter especial aos escravizados, como a capela e, principalmente, o cemitério da Santa Casa de Misericórdia, onde africanos e crioulos eram enterrados (KARASCH, 2000, p.101).

Assim, as praças e morros que abrigavam essas igrejas tinham, por vezes, um caráter duplo, de local de encontro dos escravizados e de "pelourinho", ou seja, lugar

\footnotetext{
${ }^{26}$ De acordo com o capítulo 17 do compromisso da Irmandade da Nossa Senhora da Lampadosa, admitia-se como irmão "toda pessoa de qualquer qualidade", entretanto condenava a presença de brancos e pardos nos postos de mando, ou seja, não deveriam ser admitidos a nenhum ofício da Irmandade. Entretanto, os pardos podiam ingressar à Irmandade.

${ }^{27}$ Mariza Soares destina um capítulo de seu principal trabalho para debater o compromisso da Irmandade de São Elesbão e Santa Ifigênia. Ver em: Mariza de Carvalho Soares, Devotos da cor. Identidade étnica, religiosidade e escravidão no Rio de Janeiro, século XVIII. Rio de Janeiro, Civilização Brasileira, 2000.
} 
onde fugitivos recebiam suas punições. O exemplo mais claro disso é o outrora Campo de São Domingos, onde os escravizados se reuniam quase que diariamente, e, eventualmente, para dançar em procissões religiosas em homenagem aos mortos e para coroar reis e rainhas africanas, onde, por vezes, tal celebração transbordava os "muros" da Igreja, com escravizados e libertos dançando e cantando, construindo uma forma de "reunião social" (QUINTÃO, 2002, p.37).

Assim, a partir das "frestas" da paróquia, podemos perceber uma forma de resistência cultural e de subversão da ordem. ${ }^{28}$ Essas folias podiam sair várias vezes por ano nas ruas, de acordo com os recursos das Irmandades, obtidos através de coleta de esmolas. ${ }^{29}$ Em relação à Igreja da Lampadosa, as suas folias tinham o Rei Baltazar ${ }^{30}$ homenageado como Rei Congo. O ponto crucial para análise das festas na Igreja Nossa Senhora da Lampadosa é a coroação de Reis Negros, onde pode-se perceber, a eleição de reis de diferentes nações. Essas eleições remetiam às tradições africanas da sucessão hereditária dos reis, substituídas nas irmandades por tal sistema eletivo, dando nova interpretação e significado à prática (QUINTÃO, 2002, p.39). Ainda no século XVIII, há notícias de um rei rebolo-tundá. ${ }^{31}$ Já no século XIX, em 1811, há fontes

\footnotetext{
28 Segundo João José Reis, as festas de santos eram a data máxima do calendário das Irmandades, onde os irmãos e irmãs saíam das confrarias com suas roupas de gala, bandeiras, danças e batuques, onde o sagrado e o profano frequentemente se fundiam. ". Ver em: REIS, João José. A morte é uma festa: ritos fúnebres e revolta popular no Brasil do século XIX. Companhia das Letras, 1991.

${ }^{29}$ Biblioteca Nacional: II-34,28,017.

30 Mediante às tradições luso-brasileiras, além do conhecido São Benedito (que deu nome à uma conhecida Irmandade), outros três santos negros nasceram na África: um deles foi o Santo Rei Baltazar, um dos Três Magos (ou Três Reis). Ver em: ABREU, Martha. O império do Divino: festas religiosas e cultura popular no Rio de Janeiro, 1830-1900. Rio de Janeiro: Nova Fronteira, 1999; KARASCH, Mary. Construindo comunidades: as irmandades dos pretos e pardos. História Revista, v. 15, n. 2, p. 257-283, 2010.

31 Mariza Soares chama atenção para a coroação do rei em questão. Segundo a autora: "o já mencionado rei da nação rebolo-tunda, escavo do Conde da Cunha, primeiro vice-rei, é empossado com a concordância de seu proprietário (...) o conde autoriza a coroação de seu escravo e permite as festanças". Em: Devotos da cor. Identidade étnica, religiosidade e escravidão no Rio de Janeiro, século XVIII. Rio de Janeiro, Civilização Brasileira, 2000, p.156. Assim, a historiadora traz à tona o debate sobre
} 


\title{
artigos
}

\section{Layla Silva Ferreira}

sobre a coroação de um rei e uma rainha, ambos de nação cabundá - logo, africanos da África Central -, podendo, dessa forma, reconstruirmos a genealogia das folias da Lampadosa.

\begin{abstract}
"Apenas amanhecia o dia de Reis, o Campo de S. Domingos, nas proximidades da capela, opulentava-se de um espetáculo variado e estranho, em que moçambiques, cabundás, banguelas, rebolos, congos, cassanges, minas, a pluraridade finalmente dos representantes de nações d'África, escravos no Brasil (grifos meus), exibiam-se autênticos, cada qual com o seu característico diferencial, seu tipo próprio, sua estética privada". (MORAIS FILHO, p.281)
\end{abstract}

Melo Morais Filho, ao realizar diversos relatos em Festas e tradições populares do Brasil, traz informações sobre práticas culturais africanas. Nesse cenário, Morais Filho aparece como "folclorista", sobretudo ao comentar a relação do povo com suas crenças quando aborda as festas religiosas como "válvulas de escape" para dificuldades sociais, esbarrando em sugestões positivistas. ${ }^{32}$ A partir da leitura do capítulo "A coroação de um Rei Negro em 1748", é possível perceber, com mais detalhes, os festejos na Irmandade Nossa Senhora da Lampadosa. É válido salientar que a Irmandade foi fundada em meados de 1740 por um grupo de devotos e ficou sediada na Igreja do Rosário de S. Benedito até 1748, data da primeira coroação de reis. Ao observar a coroação realizada em 1748, percebe-se o agrupamento de escravizados de diferentes origens, expressando sua diversidade ao mesmo tempo que construíam novas identidades. Ou seja, "a construção de identidades no Novo Mundo passava pelo agrupamento e pelas relações mantidas entre diferentes nações" (SOUZA, 2002, p.251). Melo

tolerância e repressão das festas religiosas no século XIX. Sobre o tema, ver em: REIS, João José; SILVA, Eduardo. Negociação e conflito: a resistência negra no Brasil escravista. São Paulo: Companhia das Letras, 1989; SOARES, Carlos Eugênio Líbano; GOMES, Flávio dos Santos. "Com o Pé sobre um Vulcão": Africanos Minas, Identidades e a Repressão Antiafricana no Rio de Janeiro (1830-1840). Estudos AfroAsiáticos, v. 23, n. 2, 2001.

32 Para análise detalhada das obras de Melo Morais ver: RIBEIRO, Cristina Betioli. Alexandre José de Melo Morais Filho (1844-1919): A prioridade da contribuição africana na formação da literatura e cultura brasileiras. Remate de Males, v. 39, n. 1, p. 423-439, 2019. 


\title{
artigos
}

Dos muros às frestas

Morais Filho inicia a abordagem descrevendo a coroação de um rei rebolo-tundá e termina seu capítulo com os detalhes da coroação de outubro de 1811.

\begin{abstract}
"Aos seis dias do mês de outubro de 1811, nesta capela da Nossa Senhora da Lampadosa, tiveram posse e se coroaram o Rei Caetano Lopes dos Santos, e de Rainha, Maria Joaquina, ambos de nação Cabundá (grifos meus), por estarem eleitos ela sua não e por terem licença do Ilmo Sr. Intendente-Geral da Polícia, e para constar-se lhe mandou passar esse termo, no dia mês e ano acima declarado - Padre Tomás Joaquim de Melo, capelão da Irmandade". (MORAIS FILHO, p. 283)
\end{abstract}

Maria Joaquina e Caetano Lopes dos Santos, tomavam posse e eram coroados "rainha" e "rei" da Irmandade de Nossa Senhora da Lampadosa em seis de outubro de 1811. A coroação deles foi motivo para muita festa, atraindo africanos, nascidos no Brasil, cativos e/ou libertos, remontando uma tradição africana no Rio de Janeiro. A leitura da documentação extraída acima permite perceber os sentidos do termo "nação". Mariza Soares, então, chama atenção para a necessidade de "distinguir o uso do termo "nação" como emblema da identidade de procedência (nação angola, nação mina) e o uso do termo "nação" enquanto emblema de identidade étnica: a nação rebolo-tundá..." (SOARES, 2000, p.189). Assim, ao pensar a Irmandade Nossa Senhora da Lampadosa inserida no contexto do segundo sentido de nação levantado pela historiadora, é possível traçar inserções contrastivas no seio da irmandade ${ }^{33}$, a fim de entendê-la como um espaço étnico-cultural. Logo, a análise do documento em questão

\footnotetext{
33 Roberto Cardoso de Oliveira debate o conceito de identidade contrastiva que implica a ideia de "nós" diante dos "outros", esclarecendo que: "a identidade social surge como atualização do processo de identificação e envolve a noção de grupo, particularmente da grupo social". R.C. Oliveira, Identidade, etnia e estrutura social, São Paulo, Livraria Pioneira Editora, 1976, p.5. Para mais detalhamento sobre a temática, ver: Mariza de Carvalho Soares “Mina, Angola e Guiné, nomes d'África no Rio de Janeiro Setecentista". Revista Tempo, vol. 3 - n 6, dezembro de 1998
} 


\section{artigos}

Layla Silva Ferreira

abre perspectivas para identificação de pequenos grupos, que tendem desaparecer de acordo com a periodização, conforme já debatido anteriormente.

Ao fim, é necessário debater a coroação de reis negros na Irmandade Nossa Senhora da Lampadosa em 1811, sob a égide da cultura e relações de poder que continha. Conforme descrito anteriormente, o Rio de Janeiro oitocentista contou com o tráfico intensivo de Africanos Ocidentais. Logo, pensar em culturas africanas na Corte é pensar, por vezes, especialmente nas centro-africanas.

Estas deram contribuição cultural significativa às coroações de reis negros. Assim, munido de estudos-chave no que diz respeito ao rei congo, é válido abrir parênteses para localizar a presença do catolicismo negro na África. De acordo com John Thornton, autor fundamental para a temática, o catolicismo africano, sobretudo na região do Congo, pode ser entendido como uma leitura do catolicismo europeu sob viés da cosmogonia bantu, ou seja, caracteriza-se pela possibilidade de “incorporação de ritos e símbolos de outras culturas, mas utilizando seus próprios códigos culturais e aceitando aqueles como se fossem verdadeiramente seus (THORNTON, 1984, p.147 apud MATTOS, 2006, p.103). ${ }^{34}$ Partindo desse princípio, Marina de Mello e Souza enxerga que a proliferação das coroações de rei congo no século XIX deu-se em razão do significado duplo que tal reino teve. Duplo porque foi de suma importância tanto para os senhores coloniais quanto para os escravizados da África Centro-Ocidental. Logo, tal familiaridade, explicada por Thornton a partir da ideia de "catolicismo africa-

\footnotetext{
${ }^{34}$ Segundo Jhon Thornton, o "catolicismo africano" marcou presença no reino do congo antes do tráfico atlântico para a então colônia portuguesa. Ver: THORNTON, John. The development of an african catholic church in the kingdon of Kongo, 1491-1750. In: Journal of African History, 25, Printed in Great Britain, 1984, p.147-167; A África e os africanos na formação do mundo atlântico. RJ: Elsevier, 2004.
} 
no", tornou-se crucial para a construção de identidades, sendo estas reproduzidas a partir dos reinados negros realizados nas frestas das irmandades religiosas. ${ }^{35}$

Ao buscar difundir a fé católica na África, os sacerdotes encontraram dificuldades, à exceção do reino do Congo ${ }^{36}$, onde os principais chefes aceitaram o batismo a partir de 1491 adotando, então, o catolicismo como religião do poder central, todavia, sem abandonar as crenças ancestrais. O período de governo de Mbemba Nzinga (1507-1542), batizado com o nome de Afonso, considerou-se o maior momento de força do reino do Congo. Assim, o então D. Afonso I ficou conhecido como o mais importante rei católico do Congo, mantendo relações estreitas com D. João II e D. Manuel I de Portugal, apoiando, então, a disseminação “catolicismo negro" (SOUZA, 2005, p.84).

Logo, é possível entender a festa de coroação de reis congo no Brasil como indicador de identidade, expressado nas teatralizações que ocorriam nos festejos ${ }^{37}$,

35 Historiadora, Marina de Mello e Souza desenvolveu trabalhos-chave para a compreensão das
coroaçães de reis negros, sendo o principal trabalho: SOUZA, Marina de Mello e. Reis negros no Brasil
escravista. História da festa de coroação de rei congo, Belo Horizonte, Editora UFMG, 2002. Ver também:
SOUZA, Marina de Mello. Catolicismo negro no Brasil: Santos e Minkisi, uma reflexão sobre
miscigenação cultural. Afro-Ásia, n. 28, 2002; Reis do Congo no Brasil, séculos XVIII e XIX. Revista de
História, n. 152, p. 79-98, 2005. A autora, ademais, salienta a utilização do termo "rei congo" em letra
minúscula, visto que remete à uma ideia de África construída sob olhares do Novo Mundo uma
categoria abstrata de conhecimento e não uma descrição da realidade histórica.
36 Lucilene Reginaldo chama atenção para a fragmentação do antigo reino do Congo e seus impactos
no "catolicismo negro". Segundo a autora: "Após a batalha de Mbwila, em 1665 e a conseqüente
fragmentação do antigo reino do Congo, o trabalho dos missionários tornou-se mais difícil naquela
região. A marginalização política e religiosa do Congo levou à concentração dos esforços missionários
em Angola, sobretudo em Luanda, centro político e administrativo da nova conquista. Embora o Congo
continuasse como sede do bispado, desde 1628 , o prelado responsável pelo governo da diocese de
Congo e Angola passara a residir em Luanda. A jurisdição eclesiástica da diocese foi transferida para
capital do Reino de Angola tão somente em 1676." Em: REGINALDO, Lucilene. Os Rosários dos angolas:
irmandades negras, escravas e identidades africanas na Bahia setecentista. Campinas, (Tese de
Doutorado em História) - IFCH-UNICAMP 2005, p.27-28.
37 Sobre detalhes dos festejos ver: LARA, Silvia Hunold. Significados cruzados: um reinado de congos na 


\section{artigos}

Layla Silva Ferreira

como demonstram os relatos de Mello Morais Filho sobre as festas na Nossa Senhora da Lampadosa. Através das danças, estavam simbolizados elementos da formação das identidades nas comunidades que se uniam em torno destes reis, num momento de ruptura do cotidiano e de catalisação de diferentes identidades africanas, diluídas com a escravização e (re)criadas a partir de um campo cultural, mítico. (SOUZA, 2002, p.268). Tal rememoração, mesmo que simbólica, do reino africano católico aqui detaIhado, afirmava, de certa forma, uma conexão da África "coberta e descoberta" - como intitulou Robert Slenes - no Brasil a partir das experiências do tráfico atlântico e da escravidão, indicando identidades que mesmo com traços católicos remetiam às origens africanas, criando laços étnicos a partir da organização das irmandades negras.

\section{Conclusão}

Mediante o que foi exposto, torna-se notório que o chamado "catolicismo negro" realizado nas Irmandades era bem diferente do "catolicismo africano" desenvolvido no Reino do Congo; fora reinventado. As raízes culturais centro-ocidentais eram visíveis com a teatralização dos festejos, permitindo que as origens africanas fossem cultuadas entrelaçadas às práticas tradicionais católicas. Dessa forma, as festas de coroações de reis da Irmandade Nossa Senhora da Lampadosa contribuíram para consolidar as identidades negras da comunidade. Ao pensarmos no contexto do sécuIo XIX, as irmandades desempenhavam um papel de extrema importância para a desintegração do escravismo a partir das redes de sociabilidades étnicas, a integração entre escravizados e libertos, as negociações cotidianas e os festejos que ligavam o sagrado e o profano.

\footnotetext{
Bahia setentista. In: CUNHA, Maria Clementina Pereira (Org.). Carnavais e outras f(r)estas: ensaios da história social da cultura. Editora UNICAMP, 2001.
} 


\section{artigos}

Dos muros às frestas

Por fim, é possível chegar à conclusão de que pensar a relação religião-etnia é mais complexo que parece. Em um contexto escravista, a religião não poderia existir em um vazio. Existia, então, pressionada por toda a estrutura escravista, que também era extremamente complexa e multifacetada, já que os africanos, fossem eles libertos ou escravizados, viviam sob identidades étnicas que os entrelaçavam a partir da religiosidade; ou vice-versa. Dessa forma, hoje, as chamadas congadas representam uma cultura de diáspora, proveniente de uma continuidade do século XIX, por meio da ideia e reinvenção da vida a partir do coletivo. Mesmo em espaço-temporal diferente, o objetivo é similar: reinventar-se!

\section{Fontes}

Arquivo Nacional da Torre do Tombo (ANTT): Chancelaria da Ordem de Cristo - Compromisso da Irmandade de Nossa Senhora da Lampadosa, 1767.

Arquivo Nacional: Mesa de Consciência e Ordens, Irmandades do Rio de Janeiro.

Biblioteca Nacional: II-34,28,017 - Manuscrito Representação dos devotos de Santo Antônio dos Pobres da capela de Nossa Senhora da Lampadosa a S.M. solicitando auxílio para festejarem seu padroeiro.

Livro de Irmandades da Freguesia da Sé - Arquivo da Cúria Metropolitana do Rio de Janeiro (ACMRJ)

MORAES FILHO, Melo. Festas e tradições populares do Brasil. H. Garnier, 1901.

\section{Referências bibliográficas}

ABREU, Martha. 0 império do Divino: festas religiosas e cultura popular no Rio de Janeiro, 1830-1900. Rio de Janeiro, Editora Nova Fronteira, 1999.

BARTH, Frederik. O Guru, o iniciador e outras variações antropológicas. Rio de Janeiro: Contracapa. 2000. 
Layla Silva Ferreira

CHALHOUB, Sidney. Visões da liberdade: uma história das últimas décadas da escravidão da Corte. São Paulo: Companhia das Letras, 2011.

DAVIS, N.Z. Culturas do povo: Sociedade e cultura no início da França Moderna. Rio de Janeiro, Paz e terra, 1990.

DE CRAEMER, Willy; VANSINA, Jan; FOX, Renée C. Religious movements in Central Africa: a theoretical study. Comparative studies in society and history, v. 18, n. 4, p. 458-475, 1976.

DEMÉTRIO, Denise Vieira. Famílias escravas no Recôncavo da Guanabara: séculos XVII e XVIII. Niterói. Dissertação (Mestrado) - Instituto de Ciências Humanas e Filosofia, Universidade Federal Fluminense, Niterói. 2008.

FARIAS, Juliana Barreto; GOMES, Flávio dos Santos; SOARES, Carlos Eugênio Líbano. No labirinto das nações: africanos e identidade no Rio de Janeiro, século XIX. Rio de Janeiro: Arquivo Nacional. 2005.

FLORENTINO, Manolo Garcia. Em costas negras: uma história do tráfico atlântico de escravos entre a África e o Rio de Janeiro (séculos XVIII e XIX). Rio de Janeiro: Arquivo Nacional. 1995.

GOMES, Flávio dos Santos. A demografia atlântica dos africanos no Rio de Janeiro, séculos XVII, XVIII e XIX: algumas configurações a partir dos registros eclesiásticos. História, Ciências, Saúde - Manguinhos, v. 19, p. 81-106, 2012.

HALL, Gwendolyn Midlo. Cruzando o Atlântico: etnias africanas nas Américas. Topoi, Rio de Janeiro, v.6, n.10, p.29-70. 2005.

KARASCH, Mary. A vida dos escravos no Rio de Janeiro, 1808-1850. São Paulo: Companhia das Letras. 2000.

Construindo comunidades: as irmandades dos pretos e pardos. História Revista, v. 15, n. 2, p. 257-283, 2010.

LARA, Silvia Hunold. Significados cruzados: um reinado de congos na Bahia setentista. In: CUNHA, Maria Clementina Pereira (Org.). Carnavais e outras $\mathbf{f}(\mathbf{r})$ estas: ensaios da história social da cultura. Campinas, SP: Editora UNICAMP, 2001. 
MACHADO, Maria Helena. Em torno da autonomia escrava: uma nova direção para a história social da escravidão. Revista Brasileira de História, São Paulo, vol. 8, n. 16, 143-160, 1998.

MATTOS, Regiane Augusto de. De cassange, mina, benguela a gentio da Guiné: grupos étnicos e formação de identidades africanas na cidade de São Paulo (1800-1850). (Tese de Doutorado). Universidade de São Paulo, 2009.

MILLER, Joseph C. Restauração, reinvenção e recordação: recuperando identidades sob a escravização na África e face à escravidão no Brasil. Revista de História, n. 164, p. 17-64, 2011.

MINTZ, Sidney Wilfred; PRICE, Richard. The birth of African-American culture: An anthropological perspective. Beacon Press, 1992.

OLIVEIRA, Anderson José Machado de. Devoção Negra: santos pretos e catequese no Brasil colonial. Rio de Janeiro: Quartet, 2008.

OLIVEIRA, Roberto Cardoso de. Identidade, etnia e estrutura social. São Paulo. Pioneira. 1976.

QUINTÃO, Antonia Aparecida. Irmandades Negras: Outro espaço de luta e resistência (São Paulo: 1870-1890). São Paulo: ANNABLUME, 2002.

QUINTÃO, Antonia Aparecida. Lá vem meu parente: As irmandades de pretos e pardos no Rio de Janeiro e em Pernambuco. (Século XVIII). São Paulo: ANNABLUME, 2002

REGINALDO, Lucilene. Os Rosários dos angolas: irmandades negras, escravas e identidades africanas na Bahia setecentista. Campinas, (Tese de Doutorado em História) - IFCH-UNICAMP, 2005.

REIS, João J. A morte é uma festa: ritos fúnebres e revolta popular no Brasil do século XIX. São Paulo. Companhia das Letras, 1991. - Identidade e diversidade étnica nas irmandades negras no tempo da escravidão. Tempo, Rio de Janeiro, v.2, n.3, p.7-33. 1996.

REIS, João José; SILVA, Eduardo. Negociação e conflito: a resistência negra no Brasil escravista. São Paulo: Companhia das Letras, 1989. 


\section{artigos}

Layla Silva Ferreira

RIBEIRO, Cristina Betioli. Alexandre José de Melo Morais Filho (1844-1919): A prioridade da contribuição africana na formação da literatura e cultura brasileiras. Remate de Males, v. 39, n. 1, p. 423-439, 2019.

SLENES, Robert W. Malungu Ngoma vem! A África coberta e descoberta do [no] Brasil. Revista USP, n.12, dez.-fev., p.48-67. 1991-1992.

Na senzala, uma flor - Esperanças e recordações na formação da

família escrava: Brasil Sudeste, século XIX - $2^{a}$ edição - Campinas, SP: Editora UNICAMP, 2011.

SOARES, Carlos Eugênio Líbano; GOMES, Flávio dos Santos. "Com o Pé sobre um Vulcão": Africanos Minas, Identidades e a Repressão Antiafricana no Rio de Janeiro (18301840). Estudos Afro-Asiáticos, v. 23, n. 2, 2001.

SOARES, Mariza de Carvalho. A nação que se tem e a terra de onde se vem. Estudos Afro-Asiáticos, ano 26, mai-ago, 303-330, 2004.

- Devotos da cor. Identidade étnica, religiosidade e escra-

vidão no Rio de Janeiro, século XVIII. Rio de Janeiro: Civilização Brasileira. 2000.

. Mina, Angola e Guiné: nomes d'África no Rio de Janeiro setecentista. Tempo, Vol. $3 \mathrm{n}^{\circ} 6,1998$.

SOUZA, Marina de Mello e. Reis negros no Brasil escravista. História da festa de coroação de rei congo, Belo Horizonte, Editora UFMG, 2002.

. Reis do Congo no Brasil, séculos XVIII e XIX. Revista de História, n. 152, p. 79-98, 2005.

. Catolicismo negro no Brasil: Santos e Minkisi, uma reflexão

sobre miscigenação cultural. Afro-Ásia, n. 28, 2002

THORNTON, John. A África e os africanos na formação do mundo atlântico. Rio de Janeiro: Elsevier, 2004. 